\title{
THE FORMATION OF THE ENVIRONMENTAL AGENDA OF THE UNITED NATIONS GENERAL ASSEMBLY (1946-2016)
}

\author{
E.A. Bliznetskaya, E.P. Vasilenko \\ Center for Environment and Natural Resources Studies
}

\begin{abstract}
The history of an environment as an issue of the international politics pays remarkably little attention to the circumstances in which the environmental agenda develops and to its constitutive issues. The Stockholm Conference on the human environment is one of the important milestones that made the environment as an issue of international concern. However, its success would be impossible without the immense experience in addressing environmental issues gathered at the multilateral level. A review of the literature on the research topic shows that the term "environmental agenda» is not always used properly, there is a lack of empirical data to explain the "greening» of international relations. Indeed, given the fragmented nature of international environmental governance, specifically within the framework of the United Nations, it is difficult to trace the evolution of the environmental agenda from the first days of Organization to the present. For identification and definition of the content of the environmental agen$\mathrm{da}$, the authors used the content analysis of the title of the resolutions of the UN General Assembly adopted in the period from 1946 to 2016. The research identified environmental issues of high priority: sovereignty over resources, environment, sustainable development, desertification, climate, natural disasters. The analysis made it possible to track their appearance on the agenda in chronological order. Also, we identified the issues underlying the formation of the environmental agenda of the General Assembly, namely international security issues related to nuclear weapons and economic development. In addition, we examined some voting patterns on environmental issues, the dynamics of changes in the attention of UN member states to key issues such as sustainable development, desertification, climate, sovereignty over natural resources.
\end{abstract}

Key words: International agenda, United Nations General Assembly, environment, resources, desertification, sovereignty, sustainable development, environmental problems, nuclear weapon 
I

$t$ is widely accepted that environmental questions became the subject of intense discussion in the international arena after the Stockholm Conference on the $\mathrm{Hu}$ man Environment. Nevertheless, international environmental cooperation has been developing at different levels well before the Stockholm. Since the second half of the $19^{\text {th }}$ century a number of bilateral and multilateral agreements on the nature conservation have already been in place. Various international organizations engaged in environmental issues within the scope of their competence.

After only four years following the establishment of the United Nations the Economic and Social Council organized the UN Scientific Conference for the Conservation and Utilization of Resources ${ }^{1}$. The purpose of the conference was to exchange information about environmental technologies, their costs, and advantages. Since 1973, the United Nations Environment Program has been responsible for fostering international environmental agenda, but this work proceeds in parallel to other agencies of the UN system which establish environmental agendas in their respective area of expertise.

Given the fragmentation in international environmental governance, specifically within the framework of the United Nations, it is difficult to trace the evolution of the environmental agenda from the first day of Organization work to the present. It requires research of the activities of the principal bodies of the United Nations: General Assembly and Economic and Social Council. The paper presents the results of the study of the evolution of the environmental agenda based on the resolutions of the General Assembly. Following on the critical review of international agenda-setting literature, the questions we raise here are: What constitutes the international environmental agenda? Which environment issues were defined at the beginning of UNGA agenda and what issues are there today? What gives us an understanding of the dynamics of the formation and change of the environmental agenda of the General Assembly? What is the Member States' attitude to the environment conservation on the platform of the General Assembly?

\section{Definition of the «international agenda»}

Most dictionaries contain a few definitions of the «agenda»: «a list of items to be discussed at a formal meeting; a plan of things to be done or problems to be addressed; the underlying intentions or motives of a particular person or group $»^{2}$.

In the context of diplomacy, agenda is a list of issues for discussion, designed to structure the negotiation. "The agenda is a key part of all bargaining processes. It shapes the strategies actors adopt, as well as the substantive nature of any agreement that can be reached» $[11$, p. 371$]$.

\footnotetext{
1 The United Nations Scientific Conference on the Conservation and Utilization of Resources, Lake Success, NY, US, 17 August - 6 September 1949.

2 Oxford living dictionaries. [Электронный ресурс]. URL: https://en.oxforddictionaries.com/definition/agenda (дата обращения: 10.10.2018)
} 
There are many instances of international organization document titles, in which agenda is referred to as a global plan of action, for example, Agenda 21, Development Agenda, New Urban Agenda. In these documents agenda is not the only list of issues, but also a vision of how the international community should solve these problems.

The political importance of the agenda is well studied in the cases of domestic [5], foreign policy [11], as well as the UN activities [7]. Agenda setting is an important part of decision making in which selection of the issues for consequent deliberations and decisions occurs. Agenda can be seen as an object or resource of power and influence. "Through control of the agenda, some issues are organized into politics while others are organized out» [11, p. 313]. Any item on the agenda is not just a definition of the real problem, but also includes value judgments and political posturing [15].

"International agenda formation is similarly embedded in the practices of international relations, allowing for the relative lack of formalization and 'fuzziness' of these practices» [11, p. 35]. Livingstone understands practices «as the instantiation of systemic rules and relationships» and in turn, international practices structure the agenda-setting process by creating «agenda access points». Such an understanding of international agenda-setting fills an important gap in knowledge of international politics and even predicts or explains the specific outcomes. It is true for targeted agenda setting by individual actors, not collective ones. The agenda formation in intergovernmental organizations is more complicated.

Jutta Joachim [7] suggests using in analysis of the UN agenda setting the "garbage can" model, developed by Cohen and March. The model assumes that organizations "operate on the basis of a variety of inconsistent and ill-defined preferences", using trial and error approach, with ever-changing participants, who are different in the amount of time and effort they devote to different domains [6, p. 1].

According to the model, decision making in organization is a result of interaction of four independent streams - problems, solutions, participants and choice opportunities - where the first three streams "move from one choice opportunity to another in such a way that the nature of the choice, the time it takes and the problem it solves all depend on a relatively complicating intermeshing of elements". [6, p. 16] Thus, the process of introducing any issues in the organizational agenda occurs in an inconsistent fashion. Issues can remain on the agenda until successful combinations of elements and conditions for a choice (solution) will be reached.

That approach might also be relevant to the study of the formation of the UN General Assembly environmental agenda. The procedure of agenda setting in the General Assembly quite democratic (any member State may propose agenda item), although in some cases, for the inclusion of an item in the agenda requires consensus among Member States.

In our study we follow a restrictive definition of international agenda given by Steven Rothman: «the issues that States pay serious attention to in a certain period of time» [4, p. 40]. Studying the international agenda based on the documents of the UN bodies, argues Rothman, it is necessary to find a way of sifting out such issues that receive little support among the states. 


\section{The UN General Assembly as a research object}

The environmental challenge is an established research subject in political and international studies, but there is no attempt to trace evolution of the substantive content of the international environmental agenda drawing on the analysis of the General Assembly documents. Generally, scholars highlight the historical background of the modern international environmental agenda and global environmental policy [2; 4; 8]. The dominant view is that introducing environmental issues into the international agenda is related to a series of significant United Nations conferences and adoption of international environmental agreements.

The UN General Assembly is a popular research subject, mostly in studies on its role in maintaining peace and security [8], patterns of voting behavior of Member States $[1 ; 3]$ and their blocks [10]. Notably, we find only one article in which the agenda of the General Assembly was studied by the method of content analysis [13].

The choice of resolutions of the General Assembly as the source of raw materials is not only dictated by the fact this principal body has the universal competence and the very democratic rules of procedure. We also considered that states accept the General Assembly as a platform for discussing political issues, rather than «technical» ones. This underlines the specific features of the UNGA agenda: the environmental issues raised by the Member States require a political decision or cannot be addressed in specialized bodies and organizations for any reason.

\section{Studies of the content of the General Assembly's environmental agenda}

Methodology of the study. We chose the content analysis as the main method for the study. This method allows us to give a quantitative estimate and gives an opportunity to restore the chronological sequence of appearance and «vitality» of certain environmental issues in the agenda.

Research material. This study is based on the analysis of titly resolutions adopted by the UN General Assembly during the annual sessions titles from 1946 to 2016. The choice of the resolutions as the research material is explained by the absence of the official Russian translation of the General Assembly's final agendas for this period, which calls into question the reliability of the results. For analysis of the results of voting on environmental resolutions of the UN General Assembly we used the United Nations Information and Bibliographic System (UNBISnet).

Research procedure. For the most complete and accurate a content analysis we conducted it in two stages. The first step is to determine the frequency of repetition of the following words and phrases, which are the basic terms in the field of environmental protection. At the second stage, we dropped a number of terms not directly related to the General Assembly environmental activities («space», «energy», «environmental problems», «environmental perspectives»), or used in the context of organizational activities (International Seabed Authority). 
Thus, we constructed the following list:

$\begin{array}{ll}\text { Biodiversity } & \text { Millennium Summit } \\ \text { Climate } & \text { Natural resources } \\ \text { Desertification } & \text { Nature } \\ \text { Disasters } & \text { Nuclear energy } \\ \text { Ecological rehabilitation } & \text { Nuclear weapon } \\ \text { Ecology } & \text { Ocean } \\ \text { Ecotourism } & \text { Oil } \\ \text { El Niño } & \text { Pollution } \\ \text { Environment } & \text { Protection of coral reefs } \\ \text { Environmental effects } & \text { Renewable sources of energy } \\ \text { Environmental emergency } & \text { Sea } \\ \text { Environmental Norms } & \text { Solar energy } \\ \text { Environmental threats } & \text { Subsoil } \\ \text { Forest } & \text { Sustainable development } \\ \text { International watercourses } & \text { Sustainable energy } \\ \text { Law of the sea } & \text { The Millennium Declaration } \\ \text { Marine activity } & \text { Water } \\ \text { Marine environment } & \end{array}$

In addition, at this stage, we selected only those resolutions, which reflect the environmental concern of the world community in order to prevent misrepresentation of the UNGA activities in the field under study. We excluded the resolutions that dealt with the reduction of nuclear weapons and non-proliferation from the theme «nuclear weapons». This study focuses on banning testing of nuclear weapons, because of its negative consequences for the environment.

We dropped resolutions on the organizational issues from such thematic areas as «nuclear energy", "renewable sources of energy», "climate», "law of the sea», «environment» and "desertification». Using the results of the content analysis, we made a diagram (Fig. 1), reflecting the distribution of keywords based on the total number of mentions in the period from 1946 to 2016.

This diagram illustrates the trends in addressing environmental issues within the framework of the UN General Assembly. Thus, priority areas, based on the number of mentions in the titles of resolutions, are sustainable development (104 mentions), questions of sovereignty and use of resources (79), environment (61), natural disasters (59), desertification (57), climate (32) and issues related to the law of the sea in environmental context (26).

It is also worth stressing that there are acute environmental problems, as well as promising ways to solve them among the thematic areas, whose frequency of mention is minimal. Keywords include protection of coral reefs (2 references), pollution (3), forest (5) as environmental problems and solar energy (6) and ecotourism (7) as ways to reduce human impact on the environment. 


Water
The Millennium Declaration
Sustainable energy
Sustainable development
Subsoil
Solar energy
Sea
Renewable sources of energy
Protection of coral reefs
Pollution
Oil
Ocean
Nuclear weapon
Nuclear energy
Nature
Natural resources
Millennium Summit
Marine environment
Marine activity
Law of the sea
International watercourses
Forest
Environmental threats
Environmental norms
Environmental emergency
Environmental effects
Environment
El Niño
Ecotourism
Ecology
Ecological rehabilitation
Disasters
Desertification
Climate
Biodiversity
Sing

Water

The Millennium Declaration

Sustainable energy

Subsoil

Solar energy

Sea

Protection of coral reefs

Pollution

Oil

Nuclear weapon

Nuclear energy

Millennium Summit

Marine environment

Marine activity

Law of the sea

Forest

Environmental threats

Environmental norms

Environmental emergency

Environment

El Niño

Ecological rehabilitation

Disasters

Climate

Biodiversity

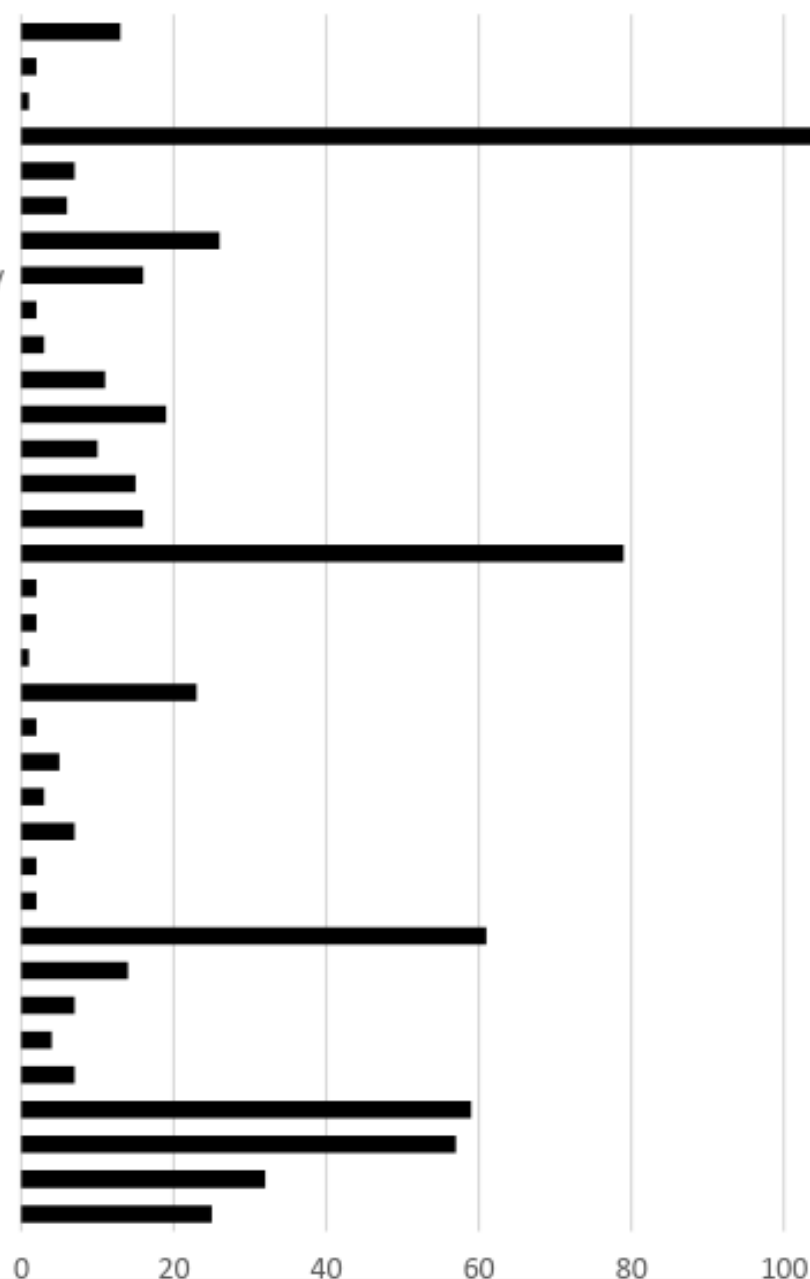

100

Fig.1. A frequency of mention of keywords from 1946 to 2016 Source: compiled by the authors

However, if we look at the diagram reflecting the chronological appearance of the keywords in the UNGA resolutions (Fig. 2), it is clear that most of the terms mentioned above were an integral part of the UNGA agenda only in the 1960s-70s. The issues of safety of nuclear energy and environmental consequences of the use of nuclear weapons were kind of «pioneers» in the environmental agenda of the General Assembly.

Starting with the first resolution, adopted five years after the founding of the UN in 1949, the resolutions on nuclear energy express the world community's concern about the possible negative impact of this type of energy on human well-being. In addition, the world community represented by the UN General Assembly calls for the peaceful use of atomic energy ${ }^{4}$, including for economic and social development ${ }^{5}$.

\footnotetext{
3 UN General Assembly resolution A/RES/299 (IV) International Control of Atomic Energy.

4 UN General Assembly resolution A/RES/912 (X) Peaceful uses of atomic energy.

${ }^{5}$ UN General Assembly resolution A/RES/32/50 Peaceful use of nuclear energy for economic and social development.
} 
The General Assembly adopted the resolutions concerning the environmental consequences of the use of nuclear weapons in the 1970s-90s in parallel with the process of the formation of the international non-proliferation regime. Most of these resolutions dealt with the ban on the deployment and use of nuclear weapons in various environments ${ }^{6,7}$.

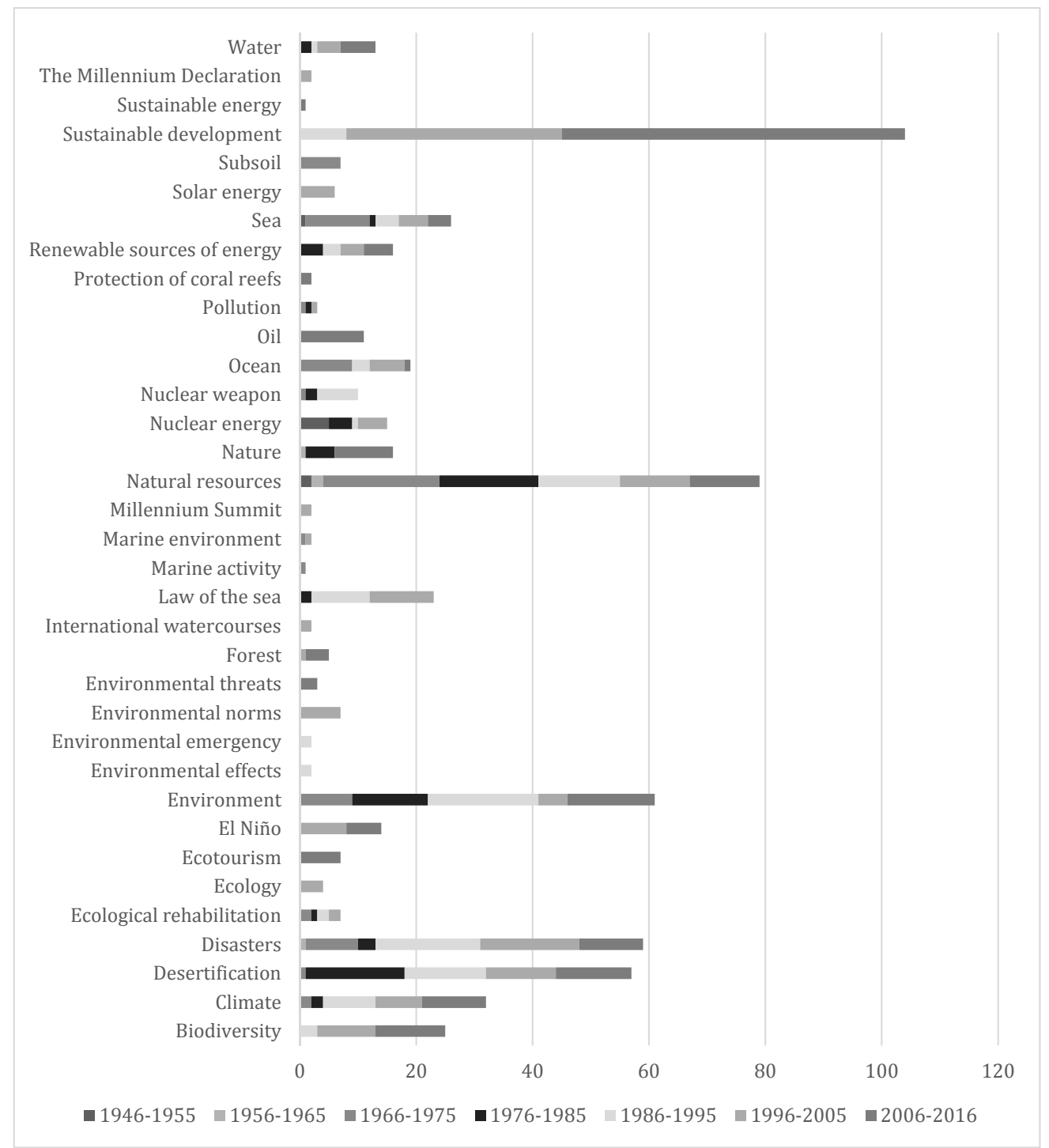

Fig.2. A frequency of mention of keywords based on the number of references for each decade from 1946 to 2016 Source: compiled by the authors

\footnotetext{
${ }^{6}$ UN General Assembly resolution A/RES/2660 (XXV) Treaty on the Prohibition of the Emplacement of Nuclear Weapons and Other Weapons of Mass Destruction on the Sea-Bed and the Ocean Floor and in the Subsoil Thereof.

7 UN General Assembly resolution A/RES/44/106 Amendment of the Treaty Banning Nuclear Weapon Tests in the Atmosphere, in Outer Space and under Water.
} 
This analysis of the adopted resolutions also allows us to say that by the 1990s, the concern of the UN member states about the negative impact on the environment spread not only on nuclear weapons, but also on all types of weapons. In particular, resolutions adopted in 1996-2002 noted the need to comply with environmental norms in the drafting and implementation of agreements on disarmament and arms control ${ }^{8}$.

The first resolution proclaiming the right to free exploitation of natural wealth and resources for all countries was adopted in $1952^{9}$. That's why, we referred this issue to the "pioneer» within the framework of the environmental agenda of the General Assembly. Data show that the problem of sovereignty over resources is also one of the most urgent questions, with a maximum of references for the period from 1966 to 1975 (Fig. 3). In recent years this issue has acquired a pronounced regional focus. Since 1973 the UN General Assembly has adopted resolutions concerning the inherent sovereignty over national resources in the occupied Arab territories almost every year ${ }^{10}$.

Also, there are resolutions within the framework of this thematic area calling for the effective use of sea resources as a way to improve the economic level of countries ${ }^{11}$. In addition, several resolutions deal with the issue of the reservation exclusively for peaceful purposes of the sea-bed and the ocean floor, and the subsoil thereof, underlying the high seas beyond the limits of present national jurisdiction, and the use of their resources in the interests of mankind ${ }^{12}$.

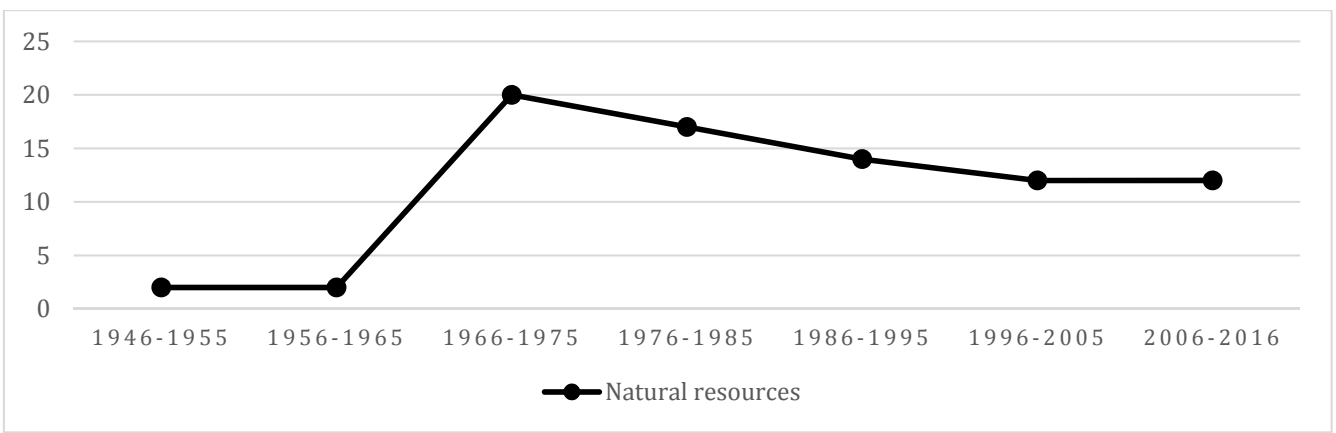

Fig.3. A frequency of mention of the keyword «Natural resources» from 1946 to 2016

\section{Source: compiled by the authors}

As mentioned above, since the late 1960s issues of special concern with respect to the environment emerged on the agenda of the General Assembly: desertification and climate. However, figure 4 shows the uneven distribution of the priorities within the work of the UN GA on these issues. The problem of desertification was a key issue

\footnotetext{
8 UN General Assembly resolution A/RES/51/45E Observance of environmental norms in the drafting and implementation of agreements on disarmament and arms control.

9 UN General Assembly resolution A/RES/626 (VII) Right to exploit freely natural wealth and resources.

${ }^{10}$ UN General Assembly resolution A/RES/3336 (XXIX) Permanent sovereignty over national resources in the occupied Arab territories.

${ }^{11}$ UN General Assembly resolution A/RES/2172 (XXI) Resources of the sea.

12 UN General Assembly resolution A/RES/2467 (XXIII) Examination of the question of the reservation exclusively for peaceful purposes of the sea-bed and the ocean floor, and the subsoil thereof, underlying the high seas beyond the limits of present national jurisdiction, and the use of their resources in the interests of mankind.
} 
only in 1976-1985, when the Action Plan to Combat Desertification ${ }^{13}$, including in the Sudano-Sahelian ${ }^{14}$ region began to implement.

Concern about issues related to climate came to the field only in 1986. At the same time, the first resolutions on this problem in the 1980s concerned the climate consequences of nuclear war, including «nuclear winter» ${ }^{15}$. The General Assembly has annually adopted resolutions on the protection of global climate for present and future generations of humankind from the end of the 80 s to the present ${ }^{16}$.

It is noted that the phrase "climate change» appeared in the environmental agenda of the UN General Assembly only in 2009 in the resolution A/RES/63/306 ${ }^{17}$.

We came to similar conclusions by considering the relationship between «environment» and «sustainable development». The term «sustainable development» appeared in UN several decades later than environmental issues. The number of mentions of «sustainable development» exceeds «environment» in 1.5 times. Moreover, it is noted that the minimum number of references to the term «environment» falls on the decade (1995-2005) when the reference to the term «sustainable development» increased from 8 to 37 (Fig. 5). We suggest that the term «sustainable development» has replaced the term «environment».

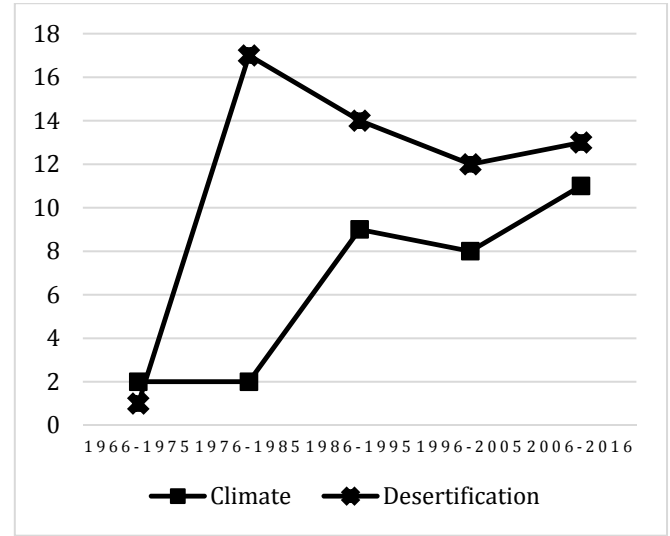

Fig.4. A frequency of mention of keywords «Climate» and «Desertification» from 1966 to 2016

Source: compiled from research materials

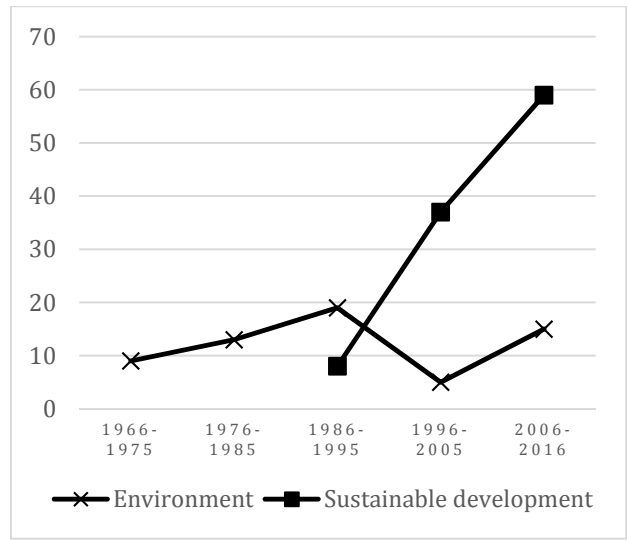

Fig.5. A frequency of mention of keywords «Environment» and «Sustainable development» from 1966 to 2016 Source: compiled from research materials

The results obtained during the content analysis allows to follow the changes in the number of keywords usage from decade to decade (Fig. 6). The first peak occurred between 1966 and 1975 when the number of environmental terms mentioned in-

\footnotetext{
${ }^{13}$ UN General Assembly resolution A/RES/33/89 Plan of Action to Combat Desertification.

${ }^{14}$ UN General Assembly resolution A/RES/34/187 Implementation in the Sudano-Sahelian region of the Plan of Action to Combat Desertification.

${ }^{15}$ UN General Assembly resolution A/RES/39/148F Climatic effects of nuclear war: nuclear winter.

${ }^{16}$ UN General Assembly resolution A/RES/70/205 Protection of global climate for present and future generations of humankind.

${ }^{17}$ UN General Assembly resolution A/RES/63/281 Climate change and its possible security implications.
} 
creased from 4 to 74 . Then in 1986-1995, it increased to 120 , and in 2016, the number of keywords in the General Assembly resolutions was 193. These quantitative changes are related to the then-ongoing international conferences on the protection of the environment and preparation for them: the Conference on the Human Environment (Stockholm, 1972), the United Nations Conference on Environment and Development (Rio de Janeiro, 1992) and the United Nations Conference on Sustainable Development (Rio de Janeiro, 2012), respectively.

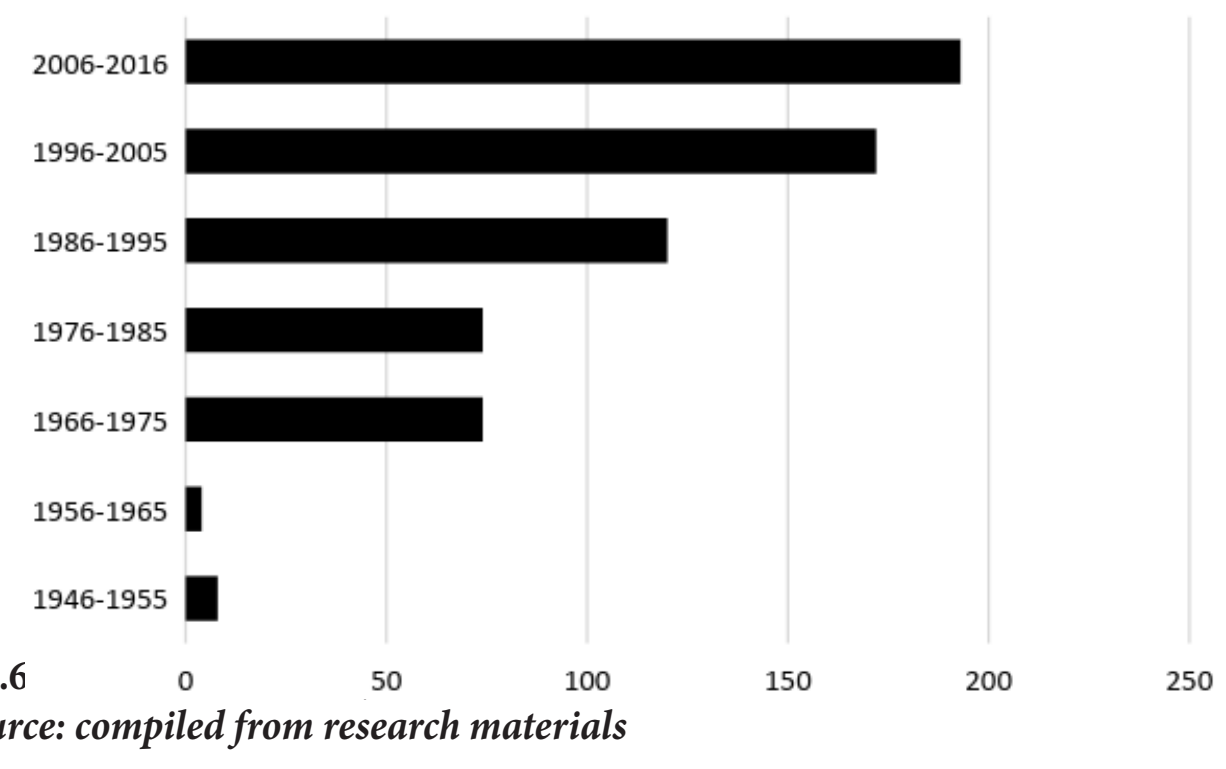

\section{Some voting patterns on environmental resolutions}

The formation of the General Assembly agenda and their substantive content depend on support from the Member States. This support includes setting the issues in the agenda of the General Assembly and in voting behavior. In turn, this support reflects the attitudes of Member States to the consideration of the environmental problems on the General Assembly platform, and to the enshrining the particular environmental issues their international significance. Analysis of the voting patterns on environmental issues provides a basis for future qualitative research.

In the practice of the General Assembly in recent years, the vast majority of resolutions have adopted by consensus. As a result, out of 645 resolutions of the UN General Assembly adopted within the framework of the environmental agenda, only 148 have been voted. Their distribution by thematic areas is as follows:

Resources (48 resolutions)

Law of the sea (38)

Armaments (19)

Environment (12)

Oil pollution (10)
Desertification (3)

Responsibility in regard to the environment (3)

Natural disasters (3)

Environmental effects (2) 
Climate (5)

Renewable sources of energy (1)

Atomic energy (4)

Based on the data presented above, the resolutions only indirectly related to protecting natural ecosystems were put to a vote in the General Assembly. The questions, directly related to the environment, were put to a vote much less often, which gives some grounds for talking about the solidarity of opinions on the importance of these problems among the countries participating in the UN General Assembly.

However, for a more comprehensive overview of the data obtained and an analysis of the attitude of countries to environmental protection activities on the margins of the UN General Assembly, it is necessary to consider in more detail the results of voting on each topic.

The question of the sovereignty of countries over their resources is not only one of the key, but also one of the most controversial, as evidenced by the following: for the period from 1945 to 2016, 79 resolutions were adopted, 48 of which were put to the vote. It is noted that in addition to the problem of sovereignty over resources, voting took place on such resolutions as «Development of the energy resources of developing countries» ${ }^{18}$, «Trends in the transfer of resources to and from developing countries and their impact on the economic growth and sustainable development of those countries» ${ }^{19}$.

It is also interesting to consider the resolutions included in the generalized thematic area "Armament». Two main issues were put to a vote: in the UN General Assemblyompliance with environmental norms in the drafting and implementation of agreements on disarmament and arms control (voted four times) and an amendment to the Treaty Banning Nuclear Weapon Tests in the Atmosphere, in Outer Space and Under Water (voted for 3 times).

\section{From nuclear winter to sustainable development: the main findings of the study}

Summarizing the results, we can identify a number of fundamental conclusions.

1. The Concern for environmental issues on the agenda of the General Assembly increased dramatically in the period from 1966 to 1975, as evidenced by an increase in the frequency of repetition of «environmental» terms and the expansion of their subjects. Subsequent outbursts (1986-1995 and 2006-2015) are explained by the preparation of the largest international conferences on environmental protection and sustainable development (the United Nations Conference on Environment and Development, the United Nations Conference on Sustainable Development).

2. The basis for the formation of the environmental agenda of the UN General Assembly is international security issues related to nuclear weapons and economic development, in particular, sovereignty over resources.

\footnotetext{
${ }^{18} \mathrm{~A} / \mathrm{RES} / 37 / 251$ «Development of the energy resources of developing countries».

${ }^{19} \mathrm{~A} / \mathrm{RES} / 44 / 232$ «Trends in the transfer of resources to and from developing countries and their impact on the economic growth and sustained development of those countries».
} 
3. Within the thematic areas, it is also possible to talk about the high priority areas for the UN General Assembly in the field of the environment. These issues are related to sovereignty over resources, the environment as a whole, sustainable development, desertification, natural disasters, as well as a number of issues on the oceans, their resources, and maritime law.

4. Most of the resolutions within the framework of the environmental agenda of the UNGA are adopted without a vote, but there are a number of resolutions on which voting is carried out from year to year. First of all, these are issues related to sovereignty over resources and compliance with environmental norms for disarmament. But these resolutions have an indirect relationship to environmental issues and are more related to political issues.

Our study focuses on substantive part of the international environmental agenda, so the collected data is not comprehensive for testing any hypothesis about international agenda-setting. We reaffirm Cohen and March's finding that problems setting into the international agenda, does not necessarily mean commence negotiations for their solution. Problems that have set in the UNGA agenda do not disappear of and by themselves. They are remaining the topic for debate for a long time, sometimes meaningfully change, and mainstreamed on multiple occasions - whether it is an international event, disaster, or just initiative of Member State. The drafting practice in the UN General Assembly resolutions listing previous decisions on the issue at hand is considerably important for maintain the "organizational memory".

Overall, results confirmed that the environmental issues became a common concern of the international community in the second half of the 60s of the 20th century and that the number of environmental issues on the international agenda has been only increasing over time.

The empirical analysis leads us to several important substantive findings. Our first observation concerns the impressive rate of introduction of the environmental issues on the agenda of the UN General Assembly. The study shows how wide and varied issues are in the environmental agenda and how vague the border between political (nuclear weapons), political-economic (sovereignty over natural resources) and the deep ecological (coral reefs, climate) problems is. The resolutions of the General Assembly reveal that environmental arguments play a significant role in the establishment of the international regime for the prohibition of testing and non-proliferation of nuclear weapons.

Another detail of the study - a chronological review - allows us to see the changing attitudes of governments toward making environmental issues. It gives us an opportunity to explain this changing by drawing on facts from the history of international relations of the second half of the 20th century. Although it requires a shift to qualitative analysis. Thus, the introduction in the 1950-s on the agenda issue of sovereignty over natural resources is linked to the decolonization process. This issue contributed to the formation of the right of states to freely exploit the natural resources under their jurisdiction. This right is complemented by the duty of states to ensure that their activities 
do not harm the environment of other states or areas outside national jurisdictions by hard-won consensus achieved during the Stockholm Conference in 1972.

The study indicates the constant increase in the number of resolutions in the UN General Assembly environmental agenda and a high degree of support from the Member States. That is a testament to the sustained the process of "greening" of international relations in general and strengthening of the UN environmental competence in particular.

\section{References:}

1. Bailey M. A., Strezhnev A., Voeten E. Estimating dynamic state preferences from United Nations voting data. Journal of Conflict Resolution, 2017, vol. 61 , no. 2 , pp. $430-456$.

2. Caldwell L. K., Weiland P. S. International environmental policy: from the twentieth to the twenty-first century. Durham, NC: Duke University Press, 1996. 496 p.

3. Carter D. B., Stone R. W. Democracy and multilateralism: the case of vote buying in the UN General Assembly. International Organization, 2015, vol. 69, no. 1, pp. 1-33.

4. Clapp J., Dauvergne P. Paths to a green world: The political economy of the global environment. MIT press, 2011. $351 \mathrm{p}$.

5. Cobb R. W., Elder C. D. The politics of agendabuilding: An alternative perspective for modern democratic theory. The Journal of Politics, 1971, vol. 33 , no. 4 , pp. 892-915.

6. Cohen M. D., March J. G., Olsen J. P. A garbage can model of organizational choice. Administrative science quarterly, 1972, vol. 17, no. 1, pp. 1-25.

7. Joachim J. M. Agenda setting, the UN, and NGOs: Gender violence and reproductive rights. Georgetown University Press, 2007. 256 p.

8. Kenny C. Responsibility to recommend: the role of the UN General Assembly in the maintenance of international peace and security. Journal on the Use of Force and International Law, 2016, vol. 3, no. 1, pp. 3-36.

9. Kopylov M. N., Kopylov S. M., Mohammad S. A. How the UN governing function in the field of environmental protection has been formed. RUDN Journal of Law, 2013, no. 4, pp. 302-308.

10. Kurşun A. M., Parlar Dal E. An Analysis of Turkey's and BRICS' Voting Cohesion in the UN General Assembly during 2002-2014. Global Policy, 2017, vol. 8, no. 2, pp. 191-201.

11. Livingston S. G. The politics of international agenda-setting: Reagan and North-South relations. International Studies Quarterly, 1992, vol. 36, no. 3, p. 315.

12. Mckibben H. E. To Link or Not to Link? Agenda Change in International Bargaining. British Journal of Political Science, 2016, vol. 46, no. 2 , pp. 371-393.

13. Petersen K. S. The agendas of the United Nations General Assembly: A content analysis. The Southwestern Social Science Quarterly, 1958, vol. 39, no. 3, pp. 232-241.

14. Rothman S.B. Explaining the international agenda: frames and power in politics: dissertation. University of Oregon, 2009. 254 p.

\section{About the authors:}

Ekaterina A. Bliznetskaya - Senior Researcher, Center for Environment and Natural Resources Studies. E-mail: ekate.bliznetskaya@gmail.com.

Ekaterina P. Vasilenko - Research Assistance, Center for Environment and Natural Resources Studies. E-mail: ekaterina1278@gmail.com.

The research was implemented with the financial support of the Russian Scientific Foundation; project No. 16-1810315 is implemented at the St. Petersburg State University. 


\title{
ФОРМИРОВАНИЕ ЭКОЛОГИЧЕСКОЙ ПОВЕСТКИ ДНЯ ГЕНЕРАЛЬНОЙ АССАМБЛЕИ ООН (1946-2016 гг.)
}

\author{
Е.А. Близнецкая, Е.П. Василенко \\ DOI 10.24833/2071-8160-2018-5-62-131-145
}

НП Центр изучения комплексных проблем природопользования и окружающей среды

История становления проблематики окружающей среды в качестве вопроса международной обеспокоенности удивительно мало говорит о том, в каком контексте происходило формирование экологической повестки дня, и из каких вопросов она состояла. Стокгольмская конференция по окружающей человека среде 1972 г., несомненно, одно из наиболее ярких и важных международных событий, выдвинувшее окружающую среду в статус мировой проблемы, однако её успех был бы невозможен без уже накопленного опыта попыток решения экологических вопросов на многостороннем уровне. Анализ литературы по теме исследования показал, что термин «экологическая повестка дня» далеко не всегда используется осознанно, вследствие чего возникает недостаток фактических данных для объяснения «экологизации» международных отношений. Действительно, учитывая фрагментированный характер международной природоохранной деятельности в целом, и в рамках Организации Объединённых Наций в частности, проследить эволюцию экологической повестки дня с момента создания Организации до наших дней представляется довольно сложной задачей. Для выявления содержания, основных этапов и закономерностей формирования экологической повестки дня авторы обратились к контент-анализу названий резолюций Генеральной Ассамблеи ООН, принятых в период с 1946 по 2016 гг. В результате исследования были выделены приоритетные экологические вопросы, среди которых суверенитет над ресурсами, окружающая среда и устойчивое развитие, опустынивание и климат, стихийные бедствия. Помимо этого, проведённый анализ позволил отследить их появление в повестке дня в хронологическом порядке. Также результатом исследования стало определение вопросов, лежащих в основе формирования экологической повестки дня Генеральной Ассамблеи, а именно вопросов международной безопасности, связанных с ядерным оружием, и экономического развития. В дополнение были изучены некоторые паттерны голосования по природоохранным резолюциям Генеральной Ассамблеи, динамика изменения внимания государств-членов ООН к таким ключевым проблемам как устойчивое развитие, опустынивание, климат, суверенитет над ресурсами

Ключевые слова: международная повестка дня, Генеральная Ассамблея ООН, окружающая среда, опустынивание, ресурсы, суверенитет, устойчивое развитие, экологические проблемы, ядерное оружие

\section{Список литературы}

1. Bailey M. A., Strezhnev A., Voeten E. Estimating dynamic state preferences from United Nations voting data //Journal of Conflict Resolution. 2017. Vol. 61. No. 2. Pp. 430-456.
2. Caldwell L. K., Weiland P. S. International environmental policy: from the twentieth to the twenty-first century. Durham, NC: Duke University Press, 1996. $496 \mathrm{p}$. 
3. Carter D. B., Stone R. W. Democracy and multilateralism: the case of vote buying in the UN General Assembly // International Organization. 2015. Vol. 69. No. 1. Pp. 1-33.

4. Clapp J., Dauvergne P. Paths to a green world: The political economy of the global environment. MIT press, 2011. $351 \mathrm{p}$.

5. Cobb R. W., Elder C. D. The politics of agenda-building: An alternative perspective for modern democratic theory // The Journal of Politics. 1971. Vol. 33. No.. 4. Pp. 892-915.

6. Cohen M. D., March J. G., Olsen J. P. A garbage can model of organizational choice // Administrative science quarterly. 1972. Vol. 17. No. 1. Pp. 1-25.

7. Joachim J. M. Agenda setting, the UN, and NGOs: Gender violence and reproductive rights. Georgetown University Press, 2007. 256 p.

8. Kenny C. Responsibility to recommend: the role of the UN General Assembly in the maintenance of international peace and security //Journal on the Use of Force and International Law. 2016. Vol. 3. No. 1. Pp. 3-36.
9. Kopylov M. N., Kopylov S. M., Mohammad S. A. How the UN governing function in the field of environmental protection has been formed // RUDN Journal of Law. 2013. No. 4. Pp. 302-308.

10. Kurşun A. M., Parlar Dal E. An Analysis of Turkey's and BRICS' Voting Cohesion in the UN General Assembly during 2002-2014 // Global Policy. 2017. Vol. 8. No. 2. Pp. 191-201.

11. Livingston S. G. The politics of international agenda-setting: Reagan and North-South relations // International Studies Quarterly. 1992. Vol. 36. No. 3. P. 315.

12. Mckibben H. E. To Link or Not to Link? Agenda Change in International Bargaining // British Journal of Political Science. 2016. Vol. 46. No. 2. Pp. 371-393.

13. Petersen K. S. The agendas of the United Nations General Assembly: A content analysis //The Southwestern Social Science Quarterly. 1958. Vol. 39. No. 3. Pp. 232-241.

14. Rothman S.B. Explaining the international agenda: frames and power in politics: dissertation. University of Oregon, 2009. 254 p.

\section{6 aвmopax:}

Близнецкая Екатерина Александровна - специалист НП Центр изучения комплексных проблем природопользования и окружающей среды. Россия, Москва, Проспект Вернадского, 76, 119454. E-mail: ekate.bliznetskaya@gmail.com.

Василенко Екатерина Павловна - специалист НП Центр изучения комплексных проблем природопользования и окружающей среды. Россия, Москва, Проспект Вернадского, 76, 119454. E-mail: ekaterina1278@gmail.com. 